\title{
On two new species of Mehraorchis Srivastava, 1934 (Digenea: Pleurogenidae) infecting frogs of the South Western Ghats, India
}

\section{Keloth Shinad and Puthanpurayil Kandambeth Prasadan*}

Kannur University. Department of Zoology. Ecological Parasitology and Tropical Biodiversity Laboratory. Mananthavady Campus. Wayanad - 670645, Kerala, India. Email: prasadanpk@kannuruniv.ac.in.

\begin{abstract}
Two new species of digenetic trematodes of the genus Mehraorchis infecting the freshwater frogs, Euphlyctis cyanophlyctis and Hoplobatrachus tigerinus inhabiting the South Western Ghats, India, are described with illustrations and details on the prevalence, intensity and mean abundance of infection of Mehraorchis janardanii n. sp. and Mehraorchis euphlycti n. sp. are added. $M$. janardanii n. sp. and $M$. euphlycti n. sp. are differentiated from other Mehraorchis species based on the differences in their morphology and morphometry. The prevalence of $M$. janardanii n. sp. in E. cyanophlyctis is $1.29 \%$, the intensity is 13 and the mean abundance is 0.16 . The prevalence of infection of M. euphlycti n. sp. in E. cyanophlyctis is $0.64 \%$ and in $H$. tigerinus $6.06 \%$, the intensity of infection is one in both the hosts and the mean abundance is 0.006 and 0.06 , respectively.
\end{abstract}

Keywords: Mehraorchis janardanii n. sp.; Mehraorchis euphlycti n. sp.; Mehraorchis ranarum; Euphlyctis cyanophlyctis; Hoplobatrachus tigerinus.
Received

January 8, 2021

Accepted

March 14, 2021

Released

April 30, 2021

Full Text Article

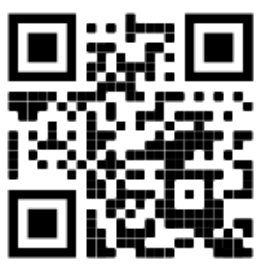

ORCID

(1) 0000-0002-3876-9697 Keloth Shinad

(1) 0000-0001-7228-8435

Puthanpurayil

Kandambeth Prasadan

\section{Introduction}

The common water skipper frog Euphlyctis cyanophlyctis (Schneider, 1799), occupies pools and standing waters in the paddy fields and sub-mountainous areas of the Western Ghats. It is usually seen at the fringes of water bodies with their eyes over water, which is floating in nature and is broadly distributed throughout South Asia (Frost, 2014). The large green frog Hoplobatrachus tigerinus (Daudin, 1803) is semi-aquatic in nature, living in the edges of rivers, paddy fields, ponds, reservoirs and swamps with floating vegetation. Two undescribed species of the genus Mehraorchis Srivastava, 1934 infecting

ISSN 2358-2731/BJBS-2021-0001/2021/8/18/4/25 
E. cyanophlyctis and $H$. tigerinus were encountered while exploring the frogs for digenetic trematodes infecting frogs of the Wayanad Region of the Western Ghats. Two undescribed species of the genus Mehraorchis Srivastava, 1934 infecting E. cyanophlyctis and H. tigerinus were encountered.

The genus Mehraorchis was erected by Srivastava (1934) with M. ranarum from Rana cyanophlyctis (E. cyanophlyctis) as its type species. So far three species, M. tigrinarum Guptā, 1954, M. jainiformis Bharadwaj, 1961 and M. cyanophlycticus Karyakarte, 1973 have been added to this genus from Indian amphibians. Guptā and Agrawal (1966) synonymised M. tigrinarum and $M$. jainiformis with $M$. ranarum and Ratnakumari et al. (1991) synonymised M. cyanophlycticus with $M$. ranarum. As of now $M$. ranarum is the only species under the genus. Life cycle of $M$. ranarum was established by Ratnakumari et al. (1991). The first report of M. ranarum from Kerala was made by Singh from the intestine of Rana tigrina in 1977.

In this paper, two new species of Mehraorchis, M. Janardanii n. sp. and M. euphlycti n. sp. infecting the frogs E. cyanophlyctis and H. tigerinus from the Wayanad Region of the Western Ghats with their prevalence, the intensity of infection and mean abundance are described. And this paper describes the second report of M. ranarum from Kerala.

\section{Materials and methods}

Study area. The study was carried out in the Western Ghats, Wayanad Region, which stands second to the Eastern Himalaya as a treasure trove of biological diversity in India (Figure 1). The Western Ghats along with its geographical extension in the wet zone of Sri Lanka is considered one of the "hottest hotspots" of biodiversity. Specimens were collected from different freshwater bodies and paddy fields of Wayanad. The map of the study area (Figure 1) was prepared using QGIS 2.16.1 software.

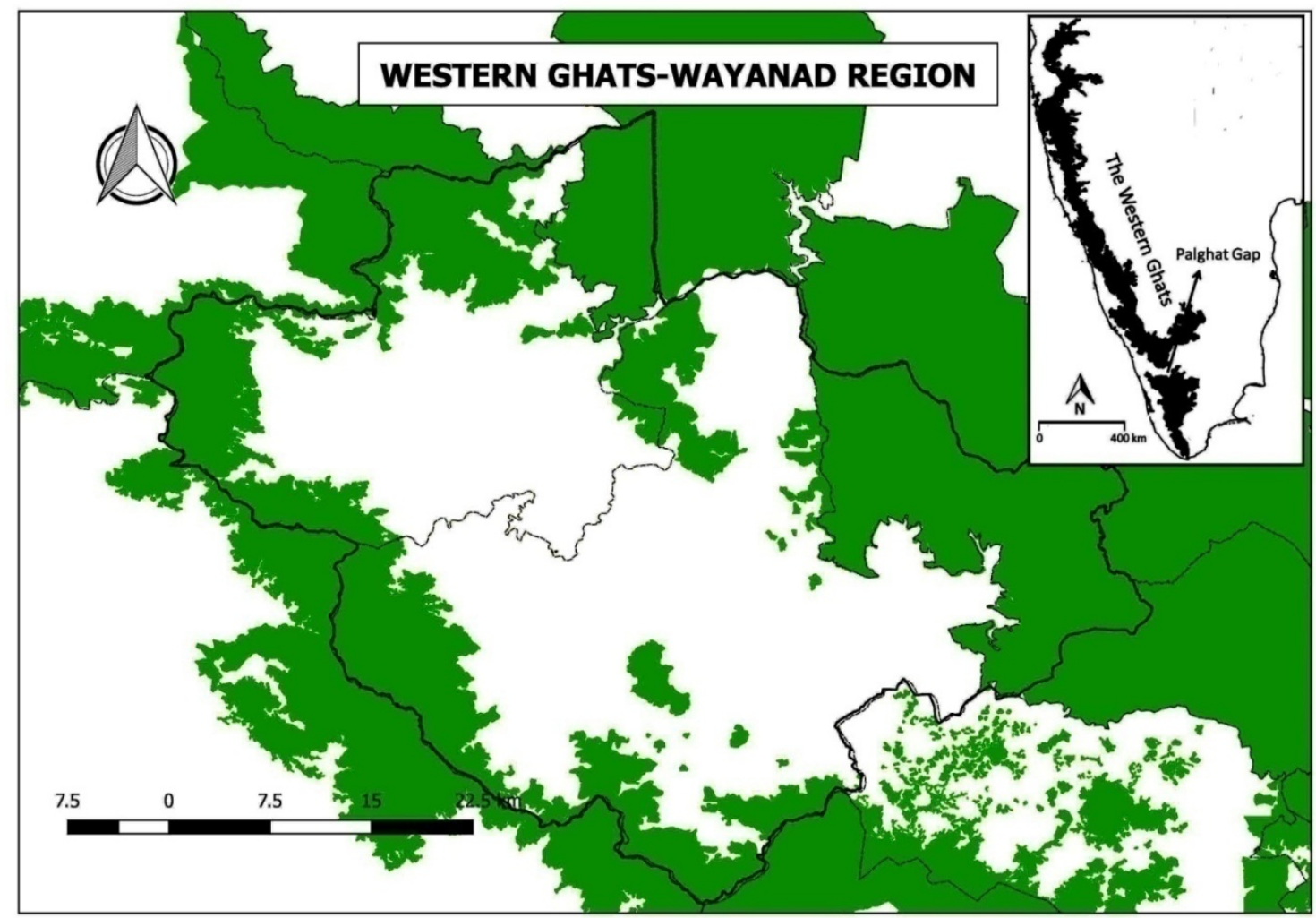

Figure 1. Study area. Western Ghats - Wayanad region. 
Parasitological studies. One hundred and fifty four hand-picked E. cyanophlyctis and $33 \mathrm{H}$. tigerinus during the period from January 2016 to March 2019 from the water bodies were brought alive to the laboratory. After narcotisation with chloroform, the frogs were dissected and the skin, muscle and other tissues were macerated to detect the presence of trematodes under a stereo zoom microscope. The intestine, gallbladder, liver, pancreas, lungs and kidney were also dissected out for the detection of trematodes. Adult trematodes from the duodenum, liver and mesenteries were transferred to $0.75 \%$ saline. Isolated parasites were examined under the Nikon phase contrast research microscope (ECLIPSE Ni-U) without supravital staining or after staining with neutral red. Permanent whole mounts of adult trematodes were prepared after fixing them in $5 \%$ formalin under slight cover glass pressure and staining with acetocarmine, following the procedure outlined by Cantwell (1981). Nikon Y-TV55 camera attached to the Nikon ECLIPSE Ni-U phase contrast research microscope was used to take photographs of the trematode. The trematodes were measured using the Nikon NIS Elements Imaging software. All measurements are in micrometers $(\mu \mathrm{m})$, as range followed by mean in parentheses. Illustrations were made using the Nikon Y-IDT drawing tube attached to the Nikon ECLIPSE Ni-U microscope and the details were added free hand from observations made on live specimens. The prevalence, the intensity of infection and the mean abundance were measured following Bush et al. (1997).

\section{Results}

\section{Mehraorchis janardanii n. sp. (Figure 2)}

Description is based on the holotype and 25 paratypes. Body ovoid, 1749.0-2270.0 (2048.0) long and 1028.0-1273.0 (1162.0) wide; prominently covered, backwardly directed spines numerous at the anterior region and gradually decrease posteriorly. Oral sucker sub terminal, slightly ovoid, almost equal to or slightly smaller than ventral sucker, $138.0-292.0 \times 169.0-353.0(219.0 \times 257.0)$ in size. Ventral sucker almost spherical, equatorial, at the level of ovary, $169.0-261.0 \times 169.0-230.0(215.0 \times 207.0)$ in diameter. Mouth sub terminal; pharynx globular, muscular, ovoid, 61.0-107.0 x 92.0-138.0 (77.0 x 119.0) in size. Oesophagus long, narrow, 215.0-291.0 (245.0) x 15.0-123.0 (49.0) in size, bifurcates into long, broad intestinal caeca having equal arms, right caecum 1151.0-1473.0 x 215.0-245.0 (1342.0 x 230.0) in size and left caecum 1151.0-1473.0 x 230.0-276.0 (1342.0 $\times 245)$ in size, extends to the level of posterior end of body.

Testes two, spherical, symmetrical, extra caecal in position, one on either side of the body, left testis slightly larger than right, right testis 153.0-230.0 x 153.0-230.0 (199.0 x 203.0) in diameter and left testis 184.0-291.0 x 184.0-261.0 (265.0 x 223.0) in diameter. Cirrus sac claviform, 337.0-476.0 x 92.0-138.0 (430.0 x 111.0), well developed, obliquely disposed, extending to intestinal bifurcation; it encloses seminal vesicles, pars-prostatica and ejaculatory duct, cirrus smooth; genital pore at left body margin close to posterior level of oral sucker and opens sub terminally. Ovary spherical or ovoid, 138.0-199.0 x 77.0-199.0 (169.0 x 130.0) in size. Uterus post ovarian, filling the posterior half of body; eggs ovoid, operculate, few in numbers and measured 15.0-31.0 x 15.0 (23.0 x 15.0). Vitellaria lateral, extending from the level of anterior region of testes to anterior margin of ovary; spreads around the testes. 
a1

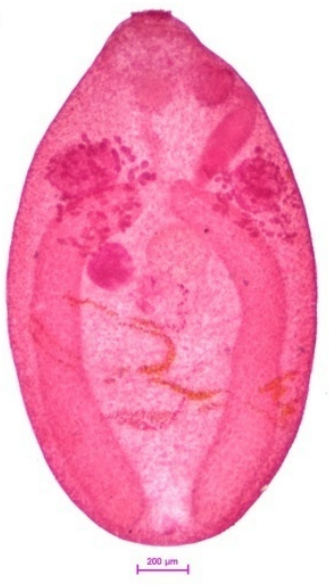

a2

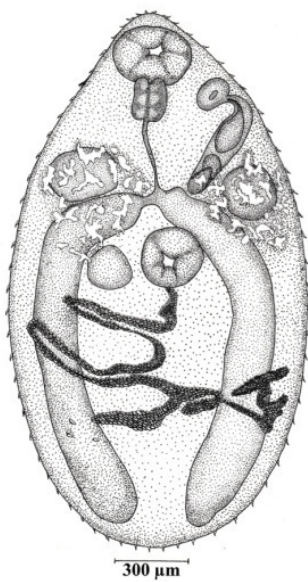

Figure 2. Mehraorchis janardanii n. sp. adult ( $\mathrm{a}_{1}$ and $\left.\mathrm{a}_{2}\right)$

Table 1. Taxonomic summary of $M$. janardanii n. sp.

\begin{tabular}{|l|l|}
\hline \multirow{2}{*}{ Holotype } & $\begin{array}{l}\text { Mehraorchis janardanii n. sp. Accession No. Z-P/H-F 154. Deposited in the } \\
\text { Helminth parasite collections, Ecological Parasitology and Tropical } \\
\text { Biodiversity Laboratory, Department of Zoology, Kannur University, } \\
\text { Mananthavady Campus, Wayanad-670645, Kerala, India. }\end{array}$ \\
\hline Hosts & E.cyanophlyctis \\
\hline Accession Nos. & $\begin{array}{l}\text { Accession No. Z-F/E-33. (Deposited in the Herpetology collections, } \\
\text { Department of Zoology, Kannur University). }\end{array}$ \\
\hline Type localities & Panamaram and Karakkuni in Wayanad District. \\
\hline Sites of infection & Duodenum and mesenteries. \\
\hline Period of collection & January 2016 to March 2019. \\
\hline Prevalence & $1.29 \%$ (two of 154 frogs screened) were infected. \\
\hline Intensity & $13(26 M$. janardanii recovered from two infected frogs). \\
\hline Mean abundance & $0.16(26$ M. janardanii recovered from a total of 154 frogs). \\
\hline
\end{tabular}

Table 2. Comparison of morphometric characters of $M$. ranarum, $M$. janardanii n. sp. and $M$. euphlycti n. sp.

\begin{tabular}{|c|c|c|c|}
\hline Characters & $\begin{array}{c}\text { M. ranarum } \\
\text { Srivasatava, } 1934\end{array}$ & M. janardanii n. sp. & M. euphlycti n. sp. \\
\hline $\begin{array}{l}\text { Body } \\
\text { LxB }\end{array}$ & $\begin{array}{l}\text { Ovoid, spinose, } 2924.0- \\
4709.0 \times 1979.0-2631.0 \\
(3414.0 \times 2205.0)\end{array}$ & $\begin{array}{l}\text { Ovoid, spinose, } 1749.0- \\
2270.0 \times 1028.0-1273.0 \\
\quad(2048.0-1162.0)\end{array}$ & $\begin{array}{c}\text { Ovoid, aspinose, } \\
\text { 2011.0-2900.0 x } \\
1323.0-1840.0(2455.0 \\
\text { x 1582.0) }\end{array}$ \\
\hline $\begin{array}{l}\text { Oral sucker } \\
\text { LxB }\end{array}$ & $\begin{array}{l}\text { Sub terminal, ovoid, } \\
149.0-361.0 \times 257.0- \\
540.0(226.0 \times 360.0)\end{array}$ & $\begin{array}{c}\text { Sub terminal, slightly } \\
\text { ovoid, } 138.0-292.0 \mathrm{x} \\
169.0-353.0(219.0 \mathrm{x} \\
257.0)\end{array}$ & $\begin{array}{c}\text { Terminal, slightly } \\
\text { ovoid, slightly smaller } \\
\text { than ventral sucker, } \\
152.0-264.0 \times 220.0- \\
415.0(208.0 \times 181.0)\end{array}$ \\
\hline $\begin{array}{l}\text { Ventral sucker } \\
\text { LxB }\end{array}$ & $\begin{array}{c}\text { Spherical, } 238.0-430.0 \\
\text { x 257.0-361.0 (321.0 x } \\
308.0)\end{array}$ & $\begin{array}{c}\text { Almost spherical, } \\
169.0-261.0 \times 169.0- \\
230.0 \\
(215.0 \times 207.0)\end{array}$ & $\begin{array}{c}\text { Ovoid, equatorial, post } \\
\text { ovarian in position, } \\
215.0-312.0 \times 246.0- \\
406.0(263.0 \times 326.0)\end{array}$ \\
\hline $\begin{array}{l}\text { Pharynx } \\
\text { LxB }\end{array}$ & Globular, $166.0 \times 157.0$ & $\begin{array}{c}\text { Globular, } \\
77.0 \times 119.0\end{array}$ & $\begin{array}{c}\text { Globular, muscular, } \\
\text { spherical, } 138.0 \times 140.0\end{array}$ \\
\hline
\end{tabular}


Table 2. Cotinued.

\begin{tabular}{|c|c|c|c|}
\hline Characters & $\begin{array}{c}\text { M. ranarum } \\
\text { Srivasatava, } 1934\end{array}$ & M. janardanii n. sp. & M. euphlycti n. sp. \\
\hline $\begin{array}{l}\text { Caeca } \\
\text { LxB }\end{array}$ & $\begin{array}{l}\text { Long, extends to the } \\
\text { level of posterior end of } \\
\text { body, right caecum } \\
1990.0-3104.0 \times 118.0- \\
192.0(2293.0 \times 146.0) \text {; } \\
\text { left caecum } 2009.0- \\
3264.0 \times 111.0-195.0 \\
(2475.0 \times 144.0)\end{array}$ & $\begin{array}{l}\text { Long, broad, extends to } \\
\text { the level of posterior } \\
\text { end of body, right } \\
\text { caecum } 1151.0-1473.0 \\
\text { x 215.0-245.0 ( } 1342.0 \times \\
\text { 230.0); left caecum } \\
1151.0-1473.0 \times 230.0- \\
276.0(1342.0 \times 245)\end{array}$ & $\begin{array}{l}\text { Long, narrow in the } \\
\text { anterior margin and } \\
\text { broad at the posterior } \\
\text { end, extends to the } \\
\text { level of posterior end of } \\
\text { body, right caecum } \\
1487.0-2161.0 \times 204.0- \\
224.0(1824.0 \times 213.0) \text {; } \\
\text { left caecum } 1418.0- \\
2072.0 \times 172.0-219.0 \\
(1745.0 \times 196)\end{array}$ \\
\hline $\begin{array}{l}\text { Oesophagus } \\
\text { LxB }\end{array}$ & $\begin{array}{c}\text { Long, narrow, } 313.0- \\
590.0 \times 37.0-62.0 \\
(447.0 \times 49.0)\end{array}$ & $\begin{array}{c}\text { Long, narrow, } 215.0- \\
291.0 \times 15.0-123.0 \\
(245.0 \times 49.0)\end{array}$ & $\begin{array}{c}\text { Long, narrow, } 265.0- \\
338.0 \times 39.0-45.0 \\
(301.0 \times 42.0)\end{array}$ \\
\hline $\begin{array}{l}\text { Testes } \\
\text { LxB }\end{array}$ & $\begin{array}{c}\text { Two, ovoid, } \\
\text { symmetrical, extra } \\
\text { caecal, left testis larger } \\
\text { than right; right testis } \\
528.0-944.0 \times 384.0- \\
539.0(675.0 \times 471.0) ; \\
\text { left testis } 475.0-955.0 \times \\
342.0-590.0(695.0 \times \\
434.0)\end{array}$ & $\begin{array}{c}\text { Two, spherical, } \\
\text { symmetrical, extra } \\
\text { caecal, left testis } \\
\text { slightly larger than } \\
\text { right, right testis } 153.0 \text { - } \\
230.0 \times 153.0-230.0 \\
(199.0 \times 203.0) ; \text { left } \\
\text { testis } 184.0-291.0 \times \\
184.0-261.0(265.0 \times \\
223.0)\end{array}$ & $\begin{array}{c}\text { Two, ovoid, } \\
\text { symmetrical, extra } \\
\text { caecal, , right testis } \\
302.0-642.0 \times 312.0- \\
419.0(472.0 \times 366.0) ; \\
\text { left testis } 414.0-535.0 \times \\
206.0-414.0(474.0 \times \\
310.0)\end{array}$ \\
\hline $\begin{array}{l}\text { Cirrus sac } \\
\text { LxB }\end{array}$ & $\begin{array}{c}\text { Claviform, well } \\
\text { developed, obliquely } \\
\text { disposed, extending to } \\
\text { intestinal bifurcation, it } \\
\text { encloses seminal } \\
\text { vesicles, pars- } \\
\text { prostatica and } \\
\text { ejaculatory duct, cirrus } \\
\text { smooth, genital pore at } \\
\text { left body margin close } \\
\text { to oral sucker; } 525.0- \\
1227.0 \times 145.0-334.0 \\
(887.0 \times 243.0)\end{array}$ & $\begin{array}{c}\text { Claviform, well } \\
\text { developed, obliquely } \\
\text { disposed, extending to } \\
\text { intestinal bifurcation, it } \\
\text { encloses seminal } \\
\text { vesicles, pars- } \\
\text { prostatica and } \\
\text { ejaculatory duct, cirrus } \\
\text { smooth, genital pore at } \\
\text { left body margin close } \\
\text { to posterior level of } \\
\text { oral sucker and } \\
\text { opening at sub } \\
\text { terminal, } 337.0-476.0 \mathrm{x} \\
\text { 92.0-138.0 (430.0 x } \\
111.0)\end{array}$ & $\begin{array}{c}\text { Claviform, well } \\
\text { developed, obliquely } \\
\text { disposed, extending to } \\
\text { intestinal bifurcation, } \\
\text { it encloses seminal } \\
\text { vesicles, pars- } \\
\text { prostatica and } \\
\text { ejaculatory duct, cirrus } \\
\text { smooth, aspinose } \\
\text { cirrus, genital pore at } \\
\text { left body margin close } \\
\text { to posterior level of } \\
\text { oral sucker and } \\
\text { opening at terminal, } \\
526.0-968.0 \times 107.0- \\
140.0(747.0 \times 123.0)\end{array}$ \\
\hline $\begin{array}{l}\text { Ovary } \\
\text { LxB }\end{array}$ & $\begin{array}{c}\text { Spherical or ovoid, } \\
176.0-297.0 \times 270.0- \\
578.0(237.0 \times 364.0)\end{array}$ & $\begin{array}{c}\text { Spherical or ovoid, } \\
138.0-199.0 \times 77.0- \\
199.0(169.0 \times 130.0)\end{array}$ & $\begin{array}{c}\text { Ovoid, 266.0-414.0 x } \\
230.0-253.0(340.0 \times \\
241.0)\end{array}$ \\
\hline Vitellaria & $\begin{array}{c}\text { Lateral, extending from } \\
\text { the level of pharynx to } \\
\text { posterior margin of } \\
\text { ovary }\end{array}$ & $\begin{array}{l}\text { Lateral, extending from } \\
\text { the level of anterior } \\
\text { region of testes to } \\
\text { anterior margin of } \\
\text { ovary; spreads around } \\
\text { the testes }\end{array}$ & $\begin{array}{l}\text { Lateral, extending from } \\
\text { the level of anterior } \\
\text { region of pharynx to } \\
\text { posterior region of } \\
\text { ovary }\end{array}$ \\
\hline $\begin{array}{l}\text { Eggs } \\
\text { LxB }\end{array}$ & $\begin{array}{c}\text { Ovoid, operculate, huge } \\
\text { in numbers, } 12.0-15.0 \times \\
18.0-21.0(14.0 \times 19.0)\end{array}$ & $\begin{array}{c}\text { Ovoid, operculate, few } \\
\text { in numbers, } 15.0-31.0 \times \\
15.0(23.0 \times 15.0)\end{array}$ & $\begin{array}{c}\text { Ovoid, operculate, } \\
\text { moderate in numbers, } \\
6.0-25.0 \times 3.0-11.0 \\
(16.0 \times 7.0)\end{array}$ \\
\hline
\end{tabular}


Table 3. Prevalence, intensity of infection and mean abundance of $M$. ranarum, M. janardanii n. sp. and M. euphlycti n. sp. in E. cyanophlyctis and H. tigerinus.

\begin{tabular}{|l|c|c|c|c|c|}
\hline Host & Trematode & $\begin{array}{c}\text { Number } \\
\text { (N) }\end{array}$ & $\begin{array}{c}\text { Prevalence } \\
\text { (\%) }\end{array}$ & Intensity & $\begin{array}{c}\text { Mean } \\
\text { abundance }\end{array}$ \\
\hline \multirow{2}{*}{ E. cyanophlyctis } & M. janardanii n. sp. & 26 & $\begin{array}{c}2 / 154 \\
(1.29)\end{array}$ & 13 & 0.16 \\
\cline { 2 - 6 } & M. euphlycti n. sp. & 1 & $\begin{array}{c}1 / 154 \\
(0.64)\end{array}$ & 1 & 0.006 \\
\hline H. tigerinus & M. euphlycti n. sp. & 2 & $\begin{array}{c}2 / 33 \\
(6.06)\end{array}$ & 1 & 0.06 \\
\hline
\end{tabular}

The prevalence of M. janardanii n. sp. in E. cyanophlyctis is $1.29 \%$, the intensity is 13 and the mean abundance is 0.16 , respectively. The prevalence of infection of M. euphlycti n. sp. in E. cyanophlyctis is $0.64 \%$ and in $H$. tigerinus $6.06 \%$, the intensity of infection is one in both the hosts and the mean abundance is 0.006 and 0.06 , respectively. A total of 29 individual trematodes (Table 3) were documented during the study, of which 26 were $M$. janardanii n. sp. and three were M. euphlycti n. sp.

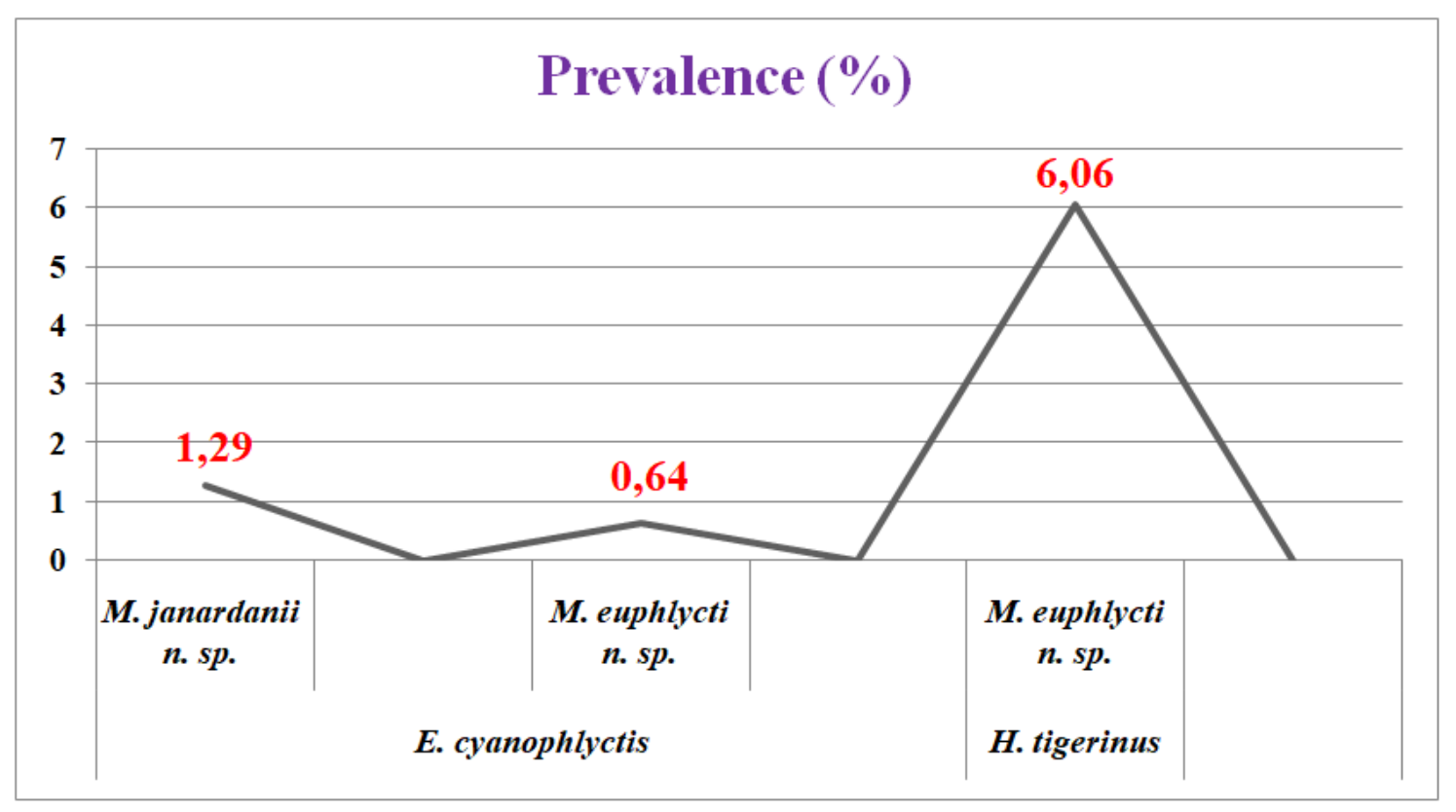

Figure 3. Prevalence of infection of $M$. janardanii n. sp. and M. euphlycti n. sp. 


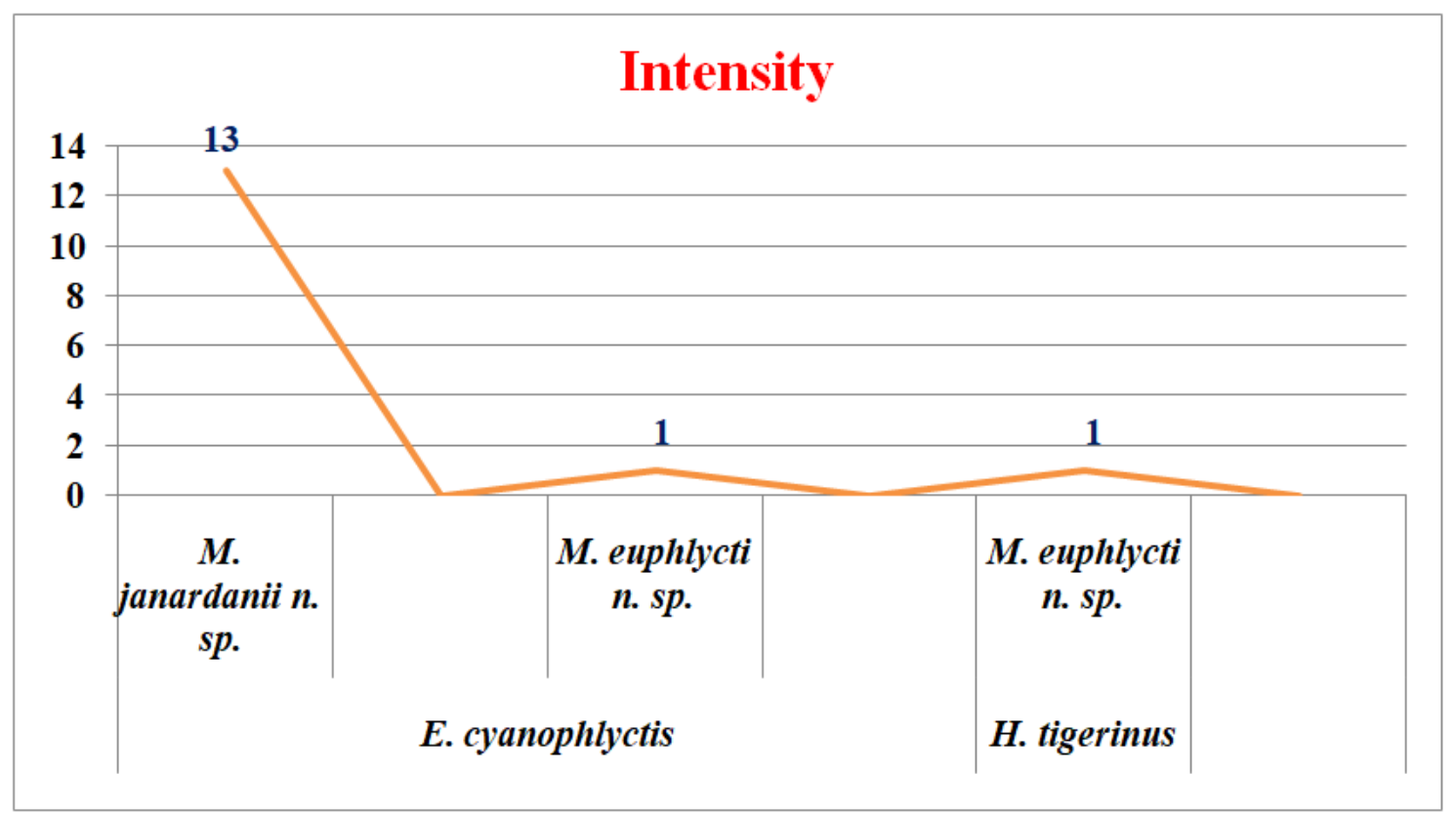

Figure 4. Intensity of infection of M. janardanii n. sp. and M. euphlycti n. sp.

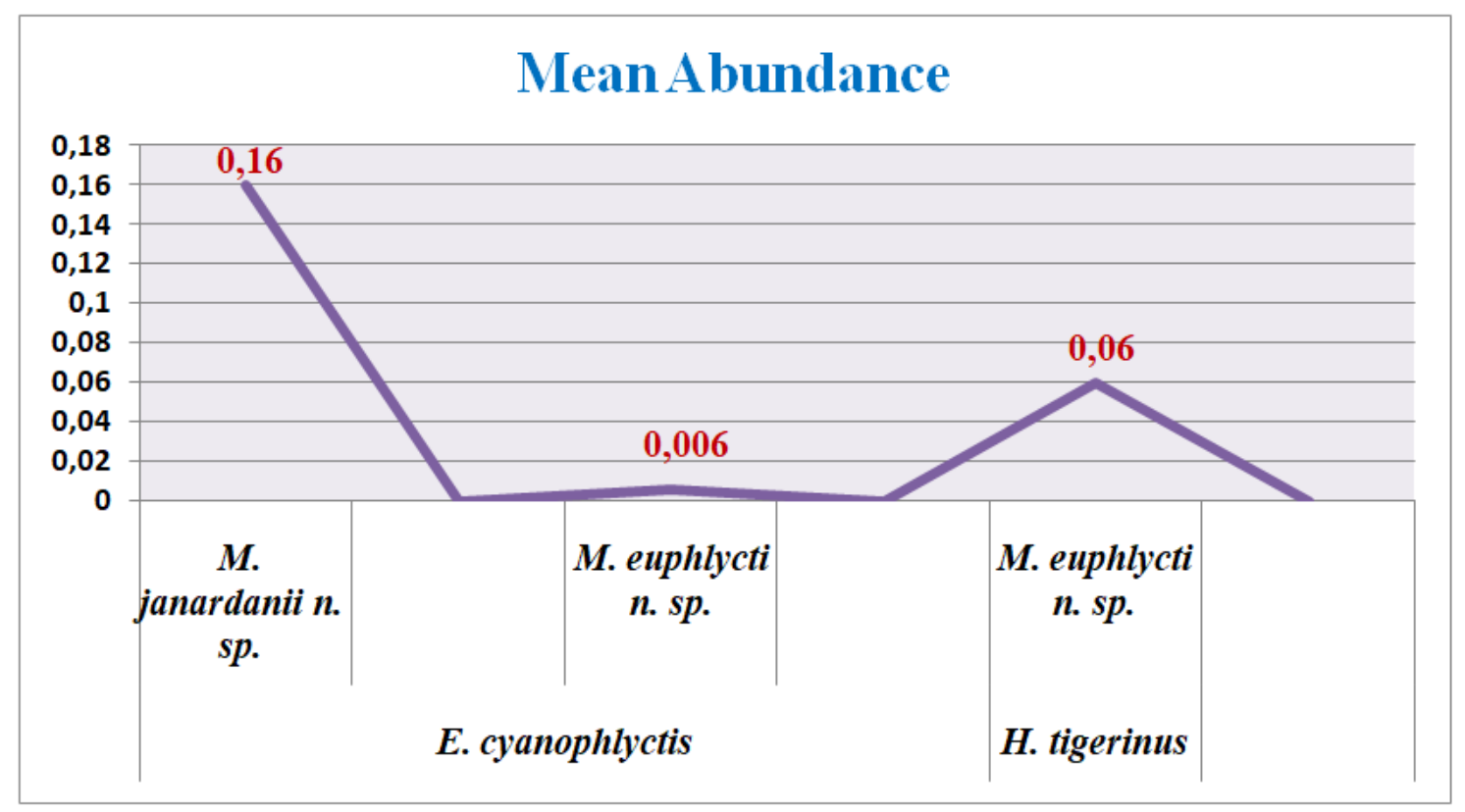

Figure 5. Mean abundance of $M$. janardanii n. sp. and $M$. euphlycti n. sp.

\section{Mehraorchis euphlycti n. sp. (Figure 6)}

Description is based on the holotype and two paratypes. Body ovoid, aspinose, 2011.0-2900.0 (2455.0) long and 1323.0-1840.0 (1582.0) wide. Oral sucker terminal, slightly ovoid, slightly smaller than ventral sucker, 152.0-264.0 x 220.0-415.0 (208.0 x 181.0 ) in size. Ventral sucker ovoid, equatorial, post ovarian in position, 215.0-312.0 x 246.0-406.0 (263.0 x 326.0) in size. Mouth terminal; pharynx globular, muscular, spherical 117.0-160.0 x 120.0-160.0 (138.0 x 140.0) in diameter. Oesophagus long, narrow, 265.0338.0 (301.0) long and 39.0-45.0 (42.0) wide, bifurcates into long intestinal caeca, long, 
narrow in the anterior margin and broad at the posterior end having equal arms, right caecum 1487.0-2161.0 x 204.0-224.0 (1824.0 x 213.0) in size and left caecum 1418.0$2072.0 \times 172.0-219.0(1745.0 \times 196)$ in size, extends to the level of posterior end of body.

Testes two, ovoid, symmetrical, extra caecal in position, one on either side of body, similar in size, right testis 302.0-642.0 x 312.0-419.0 (472.0 x 366.0) and left testis 414.0 $535.0 \times 206.0-414.0(474.0 \times 310.0)$ in size. The ratio between testes and body is approximately 1:5 in length and 1:4 in width. Cirrus sac claviform, 526.0-968.0 x 107.0140.0 (747.0 x 123.0) well developed, obliquely disposed, extending to intestinal bifurcation; it encloses seminal vesicles, pars-prostatica and ejaculatory duct; cirrus smooth, aspinose; genital pore at left body margin close to posterior level of oral sucker and opening at terminal. Ovary ovoid, 266.0-414.0 x 230.0-253.0 (340.0 x 241.0) in size. Uterus post ovarian, filling posterior half of body; eggs ovoid, operculate, moderate in numbers and measured 6.0-25.0 x 3.0-11.0 (16.0 x 7.0). Vitellaria lateral, extending from the level of anterior region of pharynx to posterior region of ovary.
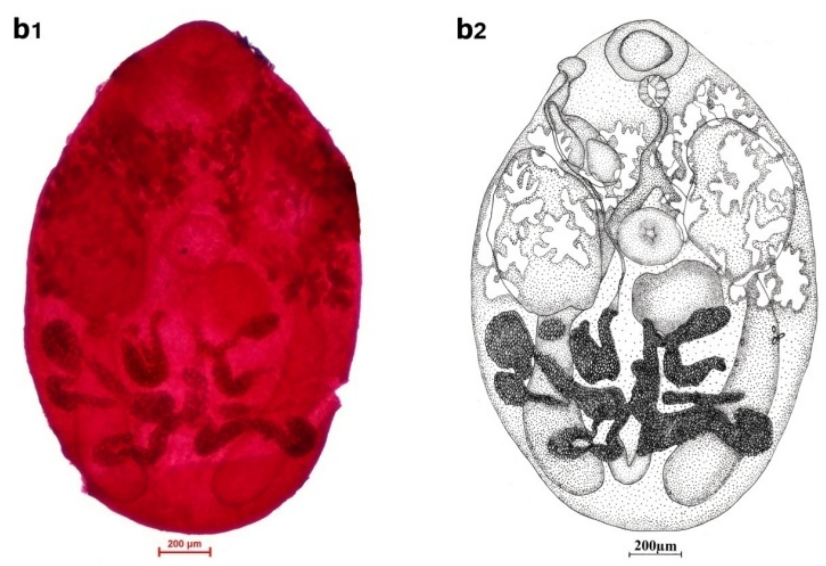

Figure 6. Mehraorchis euphlycti n. sp. adult $\left(\mathrm{b}_{1}\right.$ and $\left.\mathrm{b}_{2}\right)$

Table 4. Taxonomic summary of $M$. euphlycti n. sp.

\begin{tabular}{|c|c|c|}
\hline Holotype & \multicolumn{2}{|c|}{$\begin{array}{l}\text { Mehraorchis euphlycti n. sp. Accession No. Z-P/H-F 163. Deposited in the } \\
\text { Helminth parasite collections, Ecological Parasitology and Tropical } \\
\text { Biodiversity Laboratory, Department of Zoology, Kannur University, } \\
\text { Mananthavady Campus, Wayanad- } 670645 \text {, Kerala, India. }\end{array}$} \\
\hline Hosts & E. cyanophlyctis & H. tigerinus \\
\hline Accession Nos. & $\begin{array}{l}\text { Accession No. Z-F/E-38. (Deposited } \\
\text { in the Herpetology collections, } \\
\text { Department of Zoology, Kannur } \\
\text { University). }\end{array}$ & $\begin{array}{l}\text { Accession No. Z-F/H-25. (Deposited } \\
\text { in the Herpetology collections, } \\
\text { Department of Zoology, Kannur } \\
\text { University). }\end{array}$ \\
\hline Type localities & Karakkuni in Wayanad District. & Karakkuni in Wayanad District. \\
\hline Site of infection & Mesenteries. & On the liver. \\
\hline Period of collection & January 2016 to March 2019. & January 2016 to March 2019 \\
\hline Prevalence & $\begin{array}{l}0.64 \% \text { (One of } 154 \text { frogs screened) } \\
\text { were infected. }\end{array}$ & $\begin{array}{l}6.06 \% \text { (Two of } 33 \text { frogs screened) } \\
\text { were infected. }\end{array}$ \\
\hline Intensity & $\begin{array}{l}1 \text { (One } M \text {. euphlycti recovered from } \\
\text { one infected frog). }\end{array}$ & $\begin{array}{l}1 \text { (Two } M \text {. euphlycti recovered from } \\
\text { two infected frogs). }\end{array}$ \\
\hline Men abundance & $\begin{array}{l}0.006 \text { (One } M \text {. euphlycti recovered } \\
\text { from a total of } 154 \text { frogs). }\end{array}$ & $\begin{array}{l}0.06 \text { (Two } M . \text { euphlycti recovered } \\
\text { from a total of } 33 \text { frogs). }\end{array}$ \\
\hline
\end{tabular}




\section{Discussion}

\section{Mehraorchis janardanii n. sp.}

The described species has resemblance to M. ranarum in its body shape (Table 2). The specific investigation revealed that $M$. ranarum is different in its characters. The species is different from M. ranarum on several morphological characters like body size, shape, distribution of spines, size and shape of oral sucker, pharynx, testes and ovary, size of ventral sucker, oesophagus and cirrus sac, size, shape and nature of caeca, position and nature of opening of genital pore, nature and distribution of vitellaria and size \& number of eggs. The evident differences in the morphology and morphometry clearly indicate that the parasite is a different one and is treated as a new species. The present species is reported here as Mehraorchis janardanii n. sp. after the name of Prof. K. P. Janardanan for his immense contributions to the field of Parasitology, especially to Helminthology.

\section{Mehraorchis euphlycti n. sp.}

The described species has similarity to M. ranarum (Table 2). The detailed study revealed that the species is different from $M$. ranarum on several morphological features and morphometry like, aspinose nature and size of body, size, shape and position of oral sucker, shape of ventral sucker, size and shape of pharynx, caeca, testes and ovary, size, position and aspinose nature of cirrus sac, position and nature of opening of genital pore and the size and number of eggs. The evident differences in the morphology and morphometry definitely show that the parasite is a different one. Therefore, the present species is reported here as Mehraorchis euphlycti n. sp. after the species name of the frog host.

\section{Acknowledgements}

The authors are grateful to the Kerala State Council for Science, Technology and Environment (KSCSTE), Government of Kerala for providing financial assistance in the form of a major research project (SRS/220/2015/KSCSTE) to carry out this study. The permission accorded by the Department of Forest and Wildlife, Government of Kerala (Order No WL10-63909/2016) for collecting frogs from the Wayanad forest region is also gratefully acknowledged.

\section{Ethical approval}

All applicable international, national, and/or institutional guidelines for the care and use of animals were followed. All procedures performed in the study involving animals were in accordance with the ethical standards of the institution or practice at which the study was conducted.

\section{Conflict of interest}

The authors declare that there is no conflict of interest.

\section{References}

Bhardwaj, O. N. Morphology and taxonomy of three new species belonging to the subfamily Prosotocinae Yamaguti, 1958 (Lecithodendriidae). Proceedings of the National Academy of Sciences, India, Section B, v. 33, p. 345-354, 1961. 
Bush, A. O.; Lafferty, K. D.; Lotz, J. M.; Shostak, A. W. Parasitology meets ecology on its own terms: Margolis et al. revisited. Journal of Parasitology, v. 83, no. 4, p. 575-583, 1997.

Cantwell, G. E. Methods for invertebrates. In: Clark, G. (Ed). Staining procedures. Baltimore: Williams and Wilkins, 1981. p. 255-280.

Frost, D. R. Amphibian species of the world: An online reference. Version 6.0. New York: American Museum of Natural History, 2014. Available from: $<$ http://research.amnh.org/herpetology/amphibian/index.html>. Accessed on: Dec. 6, 2020.

Guptā, N. K. On Pleurogenes (Telogonella) swanensis n. sp. parasitic in the intestine of Rana cyanophlictis with a discussion of the systematic position of the genus Pleurogenes Looss, 1896. Research Bulletin of Punjab University, v. 58, p. 143-148, 1954.

Guptā, S. P.; Agrawal, V. Two trematode parasites of Rana cyanophlyctis from Udaipur (Rajasthan). Proceedings of the National Academy of Sciences, India, Section B, v. 36, p. 530-536, 1966.

Karyakarte, P. P. Mehrorchis cyanophlicticus sp. n. (Trematoda: Lecithodendridae) from the frog Rana cyanophlyctis India. Marathwada University Journal of Science, v. 5, p. 225228, 1973.

Ratnakumari, T. B.; Madhavi, R.; Dhanumkumari, C. The life cycle of Mehraorchis ranarum Srivastava, 1934 (Trematoda, Lecithodendriidae). Acta Parasitologica Polonica, v. 36, no. 1, p. 5-10, 1991.

Schneider, J. G. Historia Aphibiorum Naturalis et Literarariae. Fasciculus Primus. Continens Ranas, Calamitas, Bufones, Salamandras et Hydros in Genera et Species Descriptos Notisque Suis Distinctos. Jena: Friederici Frommani, 1799.

Singh, M. S. Studies on the amphibian trematodes from Tamil Nadu and Kerala. Records of Zoological Survey of India, v. 72, p. 291-294, 1977.

Srivastava, H. D. On new trematodes of frogs and fishes of the United Provinces, India. Part III. On a new genus Mehraorchis and two new species of Pleurogenes (Pleurogenetinae) with a systematic discussion and revision of the Family Lecithodendriidae. Bulletin of the Academy of Sciences of the United Provinces of Agra and Oudh, v. 3, p. 239-256, 1934.

License information: This is an open-access article distributed under the terms of the Creative Commons Attribution License, which permits unrestricted use, distribution, and reproduction in any medium, provided the original work is properly cited. 